\title{
Field Experience : Manajemen Strategis pada Proses Manajemen Keperawatan
}

\author{
Gina Meirawaty, Kurniawan Yudianto \\ Fakultas Keperawatan, Universitas Padjadjaran \\ Email : ginameirawaty@yahoo.co.id
}

\begin{abstract}
Abstrak
Pelayanan keperawatan merupakan pelayanan profesional sebagai bagian integral dari pelayanan kesehatan. Kualitas pelayanan mengacu pada sejauh mana layanan kesehatan dapat meningkat dan konsisten sesuai perkembangan pengetahuan profesional. Layanan kesehatan sesuai dengan alur pelayanan meliputi pre-admission, chec in process, stay, discharge and post-stay experience. Kajian ini bertujuan untuk meningkatkan kepuasan pasien (patient satisfaction) dan kualitas hidup pasien (quality of life). Metode pengumpulan data observasi menggunakan instrumen kualitas pelayanan, indepth interview dengan nara sumber, observasi langsung ke lapangan terkait proses keperawatan, dan telaah dokumen di ruang rawat inap, poliklinik dan IGD. hasil SWOT analisis diperoleh prioritas perbaikan analisis situasi melalui kegiatan In House Training (IHT) SP2KP Dan Role Play Teknik Komunikasi SBAR dan TBAK dengan hasil tingkat Pengetahuan dari $57 \%$ naik menjadi $69 \%$. Terdapat 2 ruang model SP2KP adalah ruang Marjan Bawah dan Agate Atas. Kajian situasional diperoleh data-data yang mendukung terhadap proses pelayanan kesehatan malalui alur pasien dari mulai pasien masuk hingga keluar meliputi kualitas pelayanan pasien berdasarkan peran dan fungsi keperawatan. Berfokus pada pilar tata kelola klinis sistem penjaminan mutu dan audit klinis serta staffing dan pengembangan profesional (CPD). Perencanaan perbaikan strategis berdasarkan prioritas rawat inap RSUD dr. Slamet Garut yang berfokus pada quality improvement meliputi $5 \mathrm{M}$ man, material, money, method dan machine. Beberapa rangkaian kegiatan yang kami rencanakan dalam mendukung intervensi dan implementasi berdasarkan kajian situasi yang telah dilakukan. Berdasarkan plan of action intervensi dilakukan terhadap peningkatan man melalui knowledge, skill dan attitude.
\end{abstract}

Kata Kunci : Kualitas pelayanan (service quality), pilar tata kelola klinis, quality improvement, SP2KP.

\begin{abstract}
Nursing services are professional services as an integral part of health services based on nursing knowledge and tips aimed at individuals, families, groups or communities both healthy and sick. Service quality refers to the extent to which health services can increase and be consistent with the development of professional knowledge. Health services in accordance with the service flow include pre-admission, check-in process, stay, discharge and post-stay experience. This study aims to improve patient satisfaction (patient satisfaction) the quality of life of patients will increase (quality of life). Methods of collecting observational data with service quality instruments, independent interviews with resource persons, direct observation in the field related to the nursing process, and review of documents and documentation in the inpatient room, polyclinic and emergency department. SP2KP In House Training (IHT) and Role Play Communication Techniques for SBAR and TBAK activities with the results of the Knowledge level of 57\% rose to 69\%. There are 2 SP2KP model rooms are the Marjan Bawah and Upper Agate rooms. Situational studies obtained data that supports the health service process through the flow of patients from the patient's entry to the exit including the quality of patient services based on nursing roles and functions. Focusing on clinical governance pillars of quality assurance and clinical audit systems and staffing and professional development (CPD). Strategic improvement planning based on the inpatient priority of Dr. Slamet Garut which focuses on quality improvement includes 5M man, material, money, method and machine. Some of the activities that we have planned to support intervention and implementation are based on a study of the situation that has been carried out. Based on the plan of action the intervention is carried out on improving man through knowledge, skill and attitude.
\end{abstract}

Keywords: Clinical governance pillar, service quality, quality improvement, SP2KP. 


\section{Pendahuluan}

Sistem manajemen adalah suatu totalitas yang terdiri dari subsistem-subsistem dengan atributnya yang satu sama yang lain saling berkaitan, saling ketergantungan, saling berinteraksi dan saling pengaruh mempengaruhi dalam penggunaan sumber daya secara efektif dan efisien sehingga mempunyai peranan, sasaran, dan tujuan tertentu. Sistem manajemen yang diterapkan oleh manajer dalam memimpin suatu organisasi tergantung pada karakter seorang manajer dan keadaan organisasi yang dipimpinnya (Asih, 2010). Sistem manajemen terdiri atas Sistem Manajemen Organisasi, Sistem Pengambilan Keputusan, Sistem Informasi Manajemen, Sistem Nilai dan Budaya Organisasi, dan Sistem Manajemen tertutup dan terbuka. Proses manajemen adalah cara sistematis dalam melakukan sesuatu terutama dalam mengelola sebuah pekerjaan atau obyek (Kusnanto, 2004).

Sistem manajemen keperawatan sesuai dengan pendekatan sistem terbuka dimana setiap komponen saling berhubungan dan berinteraksi serta dipengaruhi oleh lingkungan. Proses manajemen keperawatan merupakan suatu sistem yang terdiri dari lima elemen yaitu input, proses, output, kontrol dan mekanisme umpan balik. Input dari proses manajemen keperawatan antara lain informasi, personel, peralatan dan fasilitas. Kemampuan yang harus dimiliki pemimpin atau manajer organisasi pelayanan kesehatan meliputi kemampuan menentukan arah organisasi (visi dan misi), menentukan tujuan organisasi (goal setting), bekerja berdasarkan rencana (planning), menggunakan waktu secara efektif (time schedule), memberdayakan kemampuan staf, kemampuan memotivasi, komunikasi efektif, pengawasan dan indepensi (Kuntoro, 2010).

Proses manajemen keperawatan adalah kelompok manajer dari tingkat pengelola keperawatan tertinggi sampai ke perawat pelaksana yang mempunyai tugas dan wewenang untuk melakukan perencanaan, pengorganisasian, pengarahan dan pengawasan dalam pelaksanaan pelayanan keperawatan. Untuk melaksanakan proses manajemen diperlukan keterampilan teknik, keterampilan hubungan antar manusia,dan keterampilan konseptual (Sumijatun, 2010).

Output adalah asuhan keperawatan, pengembangan staf dan riset. Kontrol yang digunakan dalam proses manajemen keperawatan termasuk budget dari bagian keperawatan, evaluasi penampilan kerja perawat, prosedur yang standar dan akreditasi. 
Mekanisme timbal balik (feedback) berupa laporan finansial, audit keperawatan, survey kendali mutu dan penampilan kerja perawat. Berdasarkan prinsip-prinsip tersebut maka para manajer dan administrator bekerjasama dalam perencanaan dan pengorganisasian serta fungsi-fungsi manajemen lainnya untuk mencapai tujuan yang telah ditetapkan sebelumnya.

Peran dan fungsi managerial harus dilakukan perawat profesional. Untuk dapat melakukan kegiatan manajemen maka diperlukan beberapa keahlian manajemen yang dapat membantu dalam meningkatkan pelayanan kesehatan yang optimal dengan cara meningkatkan ilmu dan teknologi. Dimana teknologi digital saat ini merupakan salah satu media dalam penyampaian informasi dimasyarakat. Internet adalah salah satu teknologi digital yang mudah cara mengaksesnya sehingga penyampaian informasi dinilai lebih cepat, sehingga masyarakat sekarang dituntut melek internet baik disampaikan dalam bentuk literasi maupun sistem manajemen yang akan medukung peningkatan pelayanan kesehatan (Dewi, Janitra, \& Aristi, 2018). Tingkat keberhasilan pelayanan rumah sakit dapat dilihat dari berbagai aspek yaitu pemanfaatan sarana pelayanan, mutu pelayanan dan tingkat efisiensi pelayanan. untuk mengetahui tingkat pemanfaatan mutu pelayanan dan efisiensi pelayanan rumah sakt diperlukan berbagai indikator dan alur pelayanan yang dapat dijadikan sebagai acuan dan parameter pembanding antara fakta dan standar.

Kegiatan manajemen pelayanan tidak dapat terlepas dari alur pelayanan atau flow of care dimana melalui alur ini mengatur pergerakan pasien dalam memenuhi kebutuhan fasilitas pelayanan kesehatan. Didalam alur ini akan melibatkan pelayanan medis, peleyanan keperawatan, sumber daya fisik, dan sistem internal yang diperlukan dari mulai pasien masuk sampai pasien keluar dengan mempertahankan kualitas dan kepuasan pasien.

Alur proses pelayanan dari mulai pasien masuk hingga pulang, salah satu permalasahan yang mendapatkan keluhan terbanyak sebesar 26 keluhan pasien pada tahun 2014 di rumah sakit yaitu permasalahan alur proses yang lama pada penerimaan pasien ranap dari poli rajal, dimulai ketika dokter di poli memutuskan pasien perlu dirawat sampai pasien berbaring di tempat tidur kamar ranap dan dilakukan observasi awal pemasang infus oleh perawat. Alur proses penerimaan pasien ranap harus dilakukan 
dengan cepat karena penundaan akan meningkatkan morbiditas dan mortalitas. Penundaan akan mempengaruhi kondisi pasien (outcome) selanjutnya (Dewi, 2018).

Komunikasi antar tenaga kesehatan dalam sebuah sistem pelayanan kesehatan adalah hal utama Pengembangan standar komunikasi efektif dengan telepon dan pelatihan komunikasi bagi tenaga kesehatan merupakan dua solusi terpilih. Untuk mengidentifikasi lemahnya komunikasi telepon terutama dalam aspek penilaiaan dan konfirmasi kembali yang dapat meningkatkan risiko insiden keselamatan (Nazri, 2015).

Ada beberapa hal indikator keselamatan pasien rumah sakit yang diperhatikan salah satunya adalah komunikasi efektif SBAR (Situation Background Assessment Recommendation) dan TBAK. Kesalahan dalam berkomunikasi SBAR akan menyebabkan dampak yang tidak diinginkan pada pasien. Penelitian ini bertujuan mengeksplorasi pengalaman perawat dalam melaksanakan komunikasi efektif SBAR (Sutrisari, 2018). Komunikasi efektif secara tertulis yaitu TBAK (tulis, baca dan konfirmasi) ketika komunikasi antara pemberi dan penerima pesan berjalan dengan baik maka informasi akan diterima sesuai dengan maksud dari pemberi pesan, dampaknya pasien mendapatkan tindakan sesuai dengan kebutuhan pengobatannya dan tindakan akan terdokumentasi dengan baik (Susilowati, 2019).

\section{Metode}

Diawali dengan dilakukan kajian situasional tanggal 5 - 14 Nopember 2018, meliputi area lingkungan rumah sakit rawat inap, rawat jalan dan IGD, dengan nara sumber bidang keperawatan, komite keperawatan dan perawat yang bertugas. Metode pengumpulan data sebagai berikut :

1. Observasi dengan instrumen kualitas pelayanan

2. Indepth interview dengan nara sumber

3. Telaah dokumen dan dokumentasi

Instrumen kualitas pelayanan memuat proses alur pelayanan dari mulai pasien masuk sampai pasien pulang dimana observasi dilakukan pada tenaga kesehatan yang bertugas diruang rawat inap yang dijadikan ruang model, tenaga kesehatan disini adalah perawat, dokter jaga, petugas gizi, dan petugas farmasi. Wawancara dilakukan pada kepala ruang dan petugas ruangan untuk mengkonfirmasi mengenai pelayanan yang telah diberikan. 
Sebagai data pendukung lainnya dilakukan telaah dokumen untuk melihat proses alur pelayanan kesehatan.

Kegiatan In House Training (IHT) SP2KP dilaksanakan diruang komite keperawatan dengan jumlah peserta 60 orang yang terdiri dari ketua tim dan supervisor. Kegiatan dimulai dengan pre test tentang SP2KP dan komunikasi efektif sebanyak 10 pertanyaan. Kemudian dilanjutkan pemaparan oleh pembicara yaitu bapak Irman Somantri, S.Kp., M.Kep memberikan tentang SP2KP dan bapak Kurniawan Yudi, S.Kp., M.Kep memberikan tentang komunikasi efektif. Setelah dilakukan pemaparan dilanjutkan dengan role play SBAR dan TBAK dengan contoh kasus yang biasa ditemui di ruang rawat inap. Pada sesi akhir kegiatan dilakukan kembali post test diperoleh peningkatan $11,84 \%$ dari hasil pre test dengan grafik sebagai berikut :

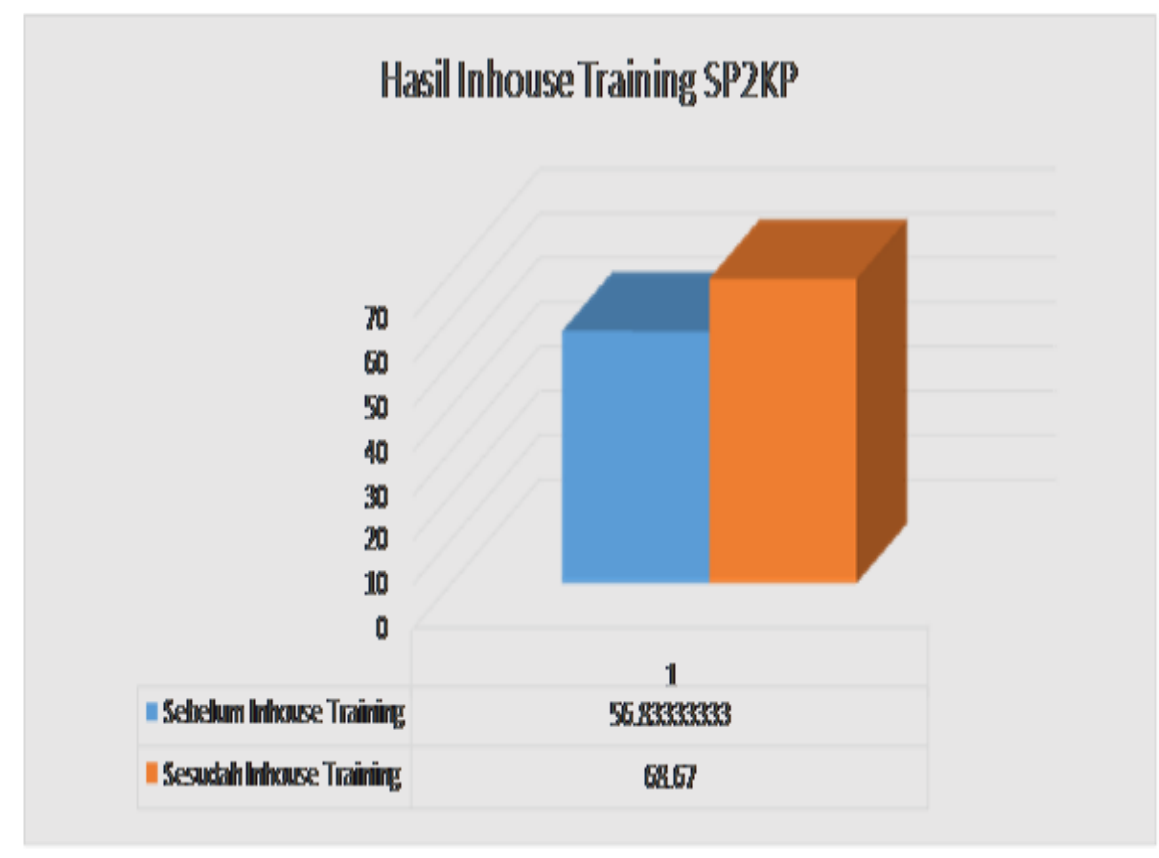

Gambar 1 Hasil Inhouse Training SP2KP 


\section{Hasil}

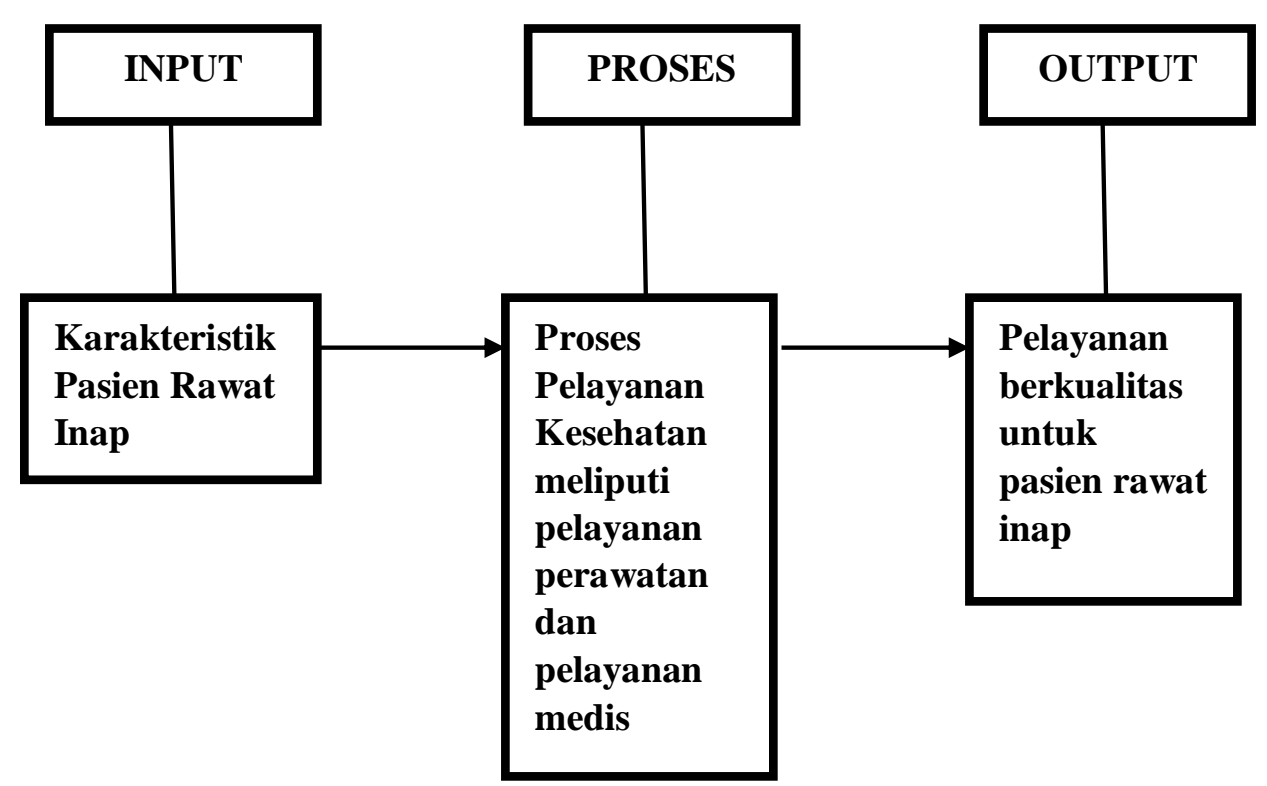

Gambar 2 Alur Proses Pelayanan Kesehatan

Alur proses pelayanan kesehatan di ruang rawat inap meliputi input, proses, dan output. Input adalah karakteristik pasien di ruang rawat inap. Proses pelayanan kesehatan meliputi pelayanan perawatan dan medis pasien (Sitorus, 2011). Output dari proses ini adalah pelayanan berkualitas untuk pasien rawat inap. Kepuasan pasien akan terpenuhi sesuai dengan kualitas pelayanan yang diberikan (Anjaryani, 2009). Dilakukan kajian strategis dimana bertujuan untuk melihat sejauh mana kondisi rumah sakit dari sisi manajemen strategis dengan indikator visi dan misi (where are we going to) dan analisis lingkungan (where are we now) sehingga hasil dari analisa SWOT rumah sakit dr. Slamet Garut berada pada Kuadran II (Diversifikasi) menggambarkan situasi bahwa meskipun rumah sakit menghadapi ancaman, namun ada kekuatan yang dapat diandalkan. Untuk itu organisasi dapat menggunakan alternatif strategi 2 yakni strategi diversifikasi atau strategi inovasi. Melakukan inovasi dalam peningkatan kualitas pelayanan kepada pasien. Hasil kajian kualitas pelayanan rawat inap 65\% cukup baik dan $35 \%$ baik. Kualitas pelayanan keperawatan berdasarkan flow of care (alur pelayanan) dengan melihat tingkat ketergantungan diperoleh hasil ketergantungan ringan kurang baik 5\%, cukup baik $60 \%$ 
dan baik 35\%. Tingkat ketergantungan sedang-berat 20\% kurang baik, 51\% cukup baik

dan $29 \%$ baik.

Hasil kajian situasi berdasarkan tata kelola klinis yang dilakukan di ruang rawat inap, poliklinik dan IGD diperoleh prioritas area need to be improve sebagai berikut :

\begin{tabular}{|c|c|c|c|c|c|c|}
\hline No & Komponen & Area Prioritas & $\begin{array}{c}\text { Langkah Pemenuhan } \\
\text { Area Prioritas }\end{array}$ & $\begin{array}{c}\text { Metode } \\
\text { Perbaikan }\end{array}$ & $\begin{array}{c}\text { Indikator } \\
\text { Pencapaian }\end{array}$ & Waktu \\
\hline \multirow[t]{7}{*}{1} & $\begin{array}{l}\text { Manajemen } \\
\text { Resiko dan } \\
\text { Patient Safety }\end{array}$ & $\begin{array}{l}\text { Ketersediaan gelang } \\
\text { identitas pasien yang } \\
\text { sangat terbatas, dan } \\
\text { labeling pasien masih } \\
\text { manual }\end{array}$ & $\begin{array}{l}\text { Pengadaan gelang } \\
\text { identitas dan labeling } \\
\text { pasien. }\end{array}$ & $\begin{array}{l}\text { Menyusun } \\
\text { anggaran }\end{array}$ & $\begin{array}{l}\text { Tersedia gelang } \\
\text { identitas dan } \\
\text { labeling pasien }\end{array}$ & 6 bulan \\
\hline & & $\begin{array}{l}\text { Kepatuhan petugas } \\
\text { dalam labeling obat - } \\
\text { obatan dengan konsetrasi } \\
\text { tinggi masih rendah }\end{array}$ & $\begin{array}{l}\text { Meningkatkan } \\
\text { kepatuhan petugas } \\
\text { dalam labeling obat - } \\
\text { obatan dengan } \\
\text { konsetrasi tinggi. }\end{array}$ & $\begin{array}{l}\text { Monitoring dan } \\
\text { pengawasan } \\
\text { berkala oleh } \\
\text { subkomite } \\
\text { manajemen } \\
\text { resiko }\end{array}$ & $\begin{array}{l}100 \% \text { obat }- \\
\text { obatan dengan } \\
\text { elektrolit pekat } \\
\text { ada labelnya }\end{array}$ & 1 bulan \\
\hline & & $\begin{array}{l}\text { Ketersediaan handrubs } \\
\text { yang sangat terbatas }\end{array}$ & Pengadaan handrubs & $\begin{array}{l}\text { Menyusun } \\
\text { anggaran }\end{array}$ & $\begin{array}{l}\text { Tersedia } \\
\text { handrubs }\end{array}$ & 6 bulan \\
\hline & & $\begin{array}{l}\text { Troley emergency tidak } \\
\text { dipergunakan } \\
\text { sebagaimana fungsinya }\end{array}$ & $\begin{array}{l}\text { Mengembalikan fungsi } \\
\text { trolley emergency } \\
\text { sebagaimana mestinya }\end{array}$ & $\begin{array}{l}\text { Monitoring dan } \\
\text { pengawasan } \\
\text { berkala oleh } \\
\text { subkomite } \\
\text { manajemen } \\
\text { resiko }\end{array}$ & $\begin{array}{l}100 \% \text { trolley } \\
\text { emergency } \\
\text { berfungsi } \\
\text { sebagaimana } \\
\text { mestinya }\end{array}$ & 1 bulan \\
\hline & & $\begin{array}{l}\text { Kepatuhan perawat } \\
\text { masih rendah dalam } \\
\text { melakukan indentifikasi } \\
\text { pasien dengan } \\
\text { menanyakan minimal } 2 \\
\text { identitas pasien yaitu: } \\
\text { nama, umur dan atau } \\
\text { tanggal lahir dilengkapi } \\
\text { dengan mencocokan } \\
\text { nomor rekam medis } \\
\text { pada gelang pasien } \\
\text { dengan nomor rekam } \\
\text { medis yang terdapat di } \\
\text { status pasien sebelum } \\
\text { melakukan tindakan } \\
\text { keperawatan. }\end{array}$ & $\begin{array}{l}\text { Meningkatkan } \\
\text { kepatuhanperawat } \\
\text { dalam melakukan } \\
\text { indentifikasi pasien } \\
\text { dengan menanyakan } \\
\text { minimal } 2 \text { identitas } \\
\text { pasien yaitu: nama, } \\
\text { umur dan atau tanggal } \\
\text { lahir dilengkapi } \\
\text { dengan mencocokan } \\
\text { nomor rekam medis } \\
\text { pada gelang pasien } \\
\text { dengan nomor rekam } \\
\text { medis yang terdapat di } \\
\text { status pasien sebelum } \\
\text { melakukan tindakan } \\
\text { keperawatan. }\end{array}$ & $\begin{array}{l}\text { Monitoring dan } \\
\text { pengawasan } \\
\text { berkala oleh } \\
\text { kepala ruang. }\end{array}$ & $\begin{array}{l}80 \% \text { perawat } \\
\text { patuh dalam } \\
\text { melakukan } \\
\text { indentifikasi } \\
\text { pasien dengan } \\
\text { menanyakan } \\
\text { minimal } 2 \\
\text { identitas pasien } \\
\text { yaitu: nama, } \\
\text { umur dan atau } \\
\text { tanggal lahir } \\
\text { dilengkapi } \\
\text { dengan } \\
\text { mencocokan } \\
\text { nomor rekam } \\
\text { medis pada } \\
\text { gelang pasien } \\
\text { dengan nomor } \\
\text { rekam medis } \\
\text { yang terdapat di } \\
\text { status pasien } \\
\text { sebelum } \\
\text { melakukan } \\
\text { tindakan } \\
\text { keperawatan. }\end{array}$ & 1 bulan \\
\hline & & $\begin{array}{l}\text { Ketersediaan stiker jatuh } \\
\text { dan symbol segitiga } \\
\text { kuning yang sangat } \\
\text { terbatas. }\end{array}$ & $\begin{array}{l}\text { Pengadaan stiker jatuh } \\
\text { dan symbol segitiga } \\
\text { kuning. }\end{array}$ & $\begin{array}{l}\text { Menyusun } \\
\text { anggaran }\end{array}$ & $\begin{array}{l}\text { Tersedia stiker } \\
\text { jatuh dan symbol } \\
\text { segitiga kuning }\end{array}$ & 6 bulan \\
\hline & & Kepatuhan perawat & Meningkatkan & Monitoring dan & $80 \%$ perawat & 1 bulan \\
\hline
\end{tabular}


Gina Meirawaty : Field Experience : Manajemen Strategis pada Proses Manajemen Keperawatan

\begin{tabular}{|c|c|c|c|c|c|c|}
\hline No & Komponen & Area Prioritas & $\begin{array}{c}\text { Langkah Pemenuhan } \\
\text { Area Prioritas }\end{array}$ & $\begin{array}{c}\text { Metode } \\
\text { Perbaikan }\end{array}$ & $\begin{array}{c}\text { Indikator } \\
\text { Pencapaian }\end{array}$ & Waktu \\
\hline & & $\begin{array}{l}\text { masih rendah dalam } \\
\text { melakukan assesmen } \\
\text { resiko jatuh terhadap } \\
\text { pasien yang baru masuk, } \\
\text { pemasangan side rail, } \\
\text { dan pengkajian ulang } \\
\text { terhadap pasien dengan } \\
\text { resiko jatuh }\end{array}$ & $\begin{array}{l}\text { kepatuhanperawatdala } \\
\text { m melakukan } \\
\text { assesmen resiko jatuh } \\
\text { terhadap pasien yang } \\
\text { baru masuk, } \\
\text { pemasangan side rail, } \\
\text { dan pengkajian ulang } \\
\text { terhadap pasien dengan } \\
\text { resiko jatuh. }\end{array}$ & $\begin{array}{l}\text { pengawasan } \\
\text { berkala oleh } \\
\text { kepala ruang }\end{array}$ & $\begin{array}{l}\text { patuh dalam } \\
\text { melakukan } \\
\text { assesmen resiko } \\
\text { jatuh terhadap } \\
\text { pasien yang baru } \\
\text { masuk, } \\
\text { pemasangan side } \\
\text { rail, dan } \\
\text { pengkajian ulang } \\
\text { terhadap pasien } \\
\text { dengan resiko } \\
\text { jatuh }\end{array}$ & \\
\hline & & $\begin{array}{l}\text { Kepatuhan perawat } \\
\text { masih rendah dalam } \\
\text { hand hygiene terutama } \\
\text { untuk } 5 \text { momen }\end{array}$ & $\begin{array}{l}\text { Meningkatkan } \\
\text { kepatuhanperawatdala } \\
\text { m hand hygiene } \\
\text { terutama untuk } 5 \\
\text { momen }\end{array}$ & $\begin{array}{l}\text { Monitoring dan } \\
\text { pengawasan } \\
\text { berkala oleh PPI }\end{array}$ & $\begin{array}{l}100 \% \text { perawat } \\
\text { patuh dalam hand } \\
\text { hygiene terutama } \\
\text { untuk } 5 \text { momen }\end{array}$ & 3 bulan \\
\hline \multirow[t]{5}{*}{2} & $\begin{array}{l}\text { Sistem } \\
\text { Penjamin Mutu } \\
\text { pelayanan } \\
\text { keperawatan } \\
\text { dan Audit } \\
\text { Klinik; } \\
\end{array}$ & $\begin{array}{l}\text { SPO penerimaan pasien } \\
\text { baru masih dalam proses } \\
\text { revisi }\end{array}$ & $\begin{array}{l}\text { Membentuk tim untuk } \\
\text { menyusun revisi SPO } \\
\text { penerimaan pasien } \\
\text { baru }\end{array}$ & $\begin{array}{l}\text { Menyusun } \\
\text { revisi SPO } \\
\text { penerimaan } \\
\text { pasien baru }\end{array}$ & $\begin{array}{l}\text { Revisi SPO } \\
\text { penerimaan } \\
\text { pasien baru sudah } \\
\text { ada }\end{array}$ & 1 bulan \\
\hline & & $\begin{array}{l}\text { Belum pernah dilakukan } \\
\text { audit mutu asuhan } \\
\text { keperawatan oleh komite } \\
\text { keperawatan melalui sub } \\
\text { komite mutu profesi }\end{array}$ & $\begin{array}{l}\text { Membentuk tim audit } \\
\text { mutu pelayanan } \\
\text { keperawatan }\end{array}$ & $\begin{array}{l}\text { Inhouse training } \\
\text { audit mutu } \\
\text { asuhan } \\
\text { keperawatan }\end{array}$ & $\begin{array}{l}\text { Sudah ada tim } \\
\text { audit mutu } \\
\text { pelayanan } \\
\text { keperawatan } \\
\text { berdasarkan SK } \\
\text { Direktur RS } \\
\end{array}$ & 1 bulan \\
\hline & & $\begin{array}{l}\text { Kepatuhan perawat } \\
\text { masih rendah dalam } \\
\text { melakukan pengkajian } \\
\text { terhadapa pasien baru } \\
\text { dan } \\
\text { mendokumentasikanya } \\
\text { di lembar status pasien }\end{array}$ & $\begin{array}{l}\text { Meningkatkan } \\
\text { kepatuhanperawatdala } \\
\text { m melakukan } \\
\text { pengkajian terhadapa } \\
\text { pasien baru dan } \\
\text { mendokumentasikanya } \\
\text { di lembar status pasien. }\end{array}$ & $\begin{array}{l}\text { Monitoring dan } \\
\text { pengawasan } \\
\text { berkala oleh } \\
\text { kepala ruang }\end{array}$ & $\begin{array}{l}80 \% \text { perawat } \\
\text { patuh dalam } \\
\text { melakukan } \\
\text { pengkajian } \\
\text { terhadapa pasien } \\
\text { baru dan } \\
\text { mendokumentasi } \\
\text { kanya di lembar } \\
\text { status pasien } \\
\end{array}$ & 1 bulan \\
\hline & & $\begin{array}{l}55 \% \text { Perawat tidak } \\
\text { mendokumentasikan } \\
\text { segala tindakan yang } \\
\text { dilakukan pada } \\
\text { pasien,serta respon dan } \\
\text { perkembangan } \\
\text { kondisinya }\end{array}$ & $\begin{array}{l}\text { Meningkatkan } \\
\text { kepatuhanperawatdala } \\
\text { m melakukan } \\
\text { pendokumentasian } \\
\text { segala tindakan yang } \\
\text { dilakukan pada } \\
\text { pasien,serta respon dan } \\
\text { perkembangan } \\
\text { kondisinya }\end{array}$ & $\begin{array}{l}\text { Monitoring dan } \\
\text { pengawasan } \\
\text { berkala oleh } \\
\text { kepala ruang }\end{array}$ & $\begin{array}{l}80 \% \text { perawat } \\
\text { patuh dalam } \\
\text { melakukan } \\
\text { pendokumentasia } \\
\text { n segala tindakan } \\
\text { yang dilakukan } \\
\text { pada pasien,serta } \\
\text { respon dan } \\
\text { perkembangan } \\
\text { kondisinya }\end{array}$ & 1 bulan \\
\hline & & $\begin{array}{l}\text { 59\% Pasien dan keluarga } \\
\text { diberikan pendidikan } \\
\text { kesehatan sesuai dengan } \\
\text { kebutuhan, berkaitan } \\
\text { dengan : terapi } \\
\text { lanjutan,nutrisi,cara } \\
\text { pemenuhan kebutuhan } \\
\text { dasar secara } \\
\text { aman,tindakan yang } \\
\text { harus dilakukan bila } \\
\text { terjadi }\end{array}$ & $\begin{array}{l}\text { Meningkatkan } \\
\text { kepatuhanperawatdala } \\
\text { m melakukan } \\
\text { pendidikan kesehatan } \\
\text { kepada pasien sesuai } \\
\text { dengan kebutuhan } \\
\text { pasien }\end{array}$ & $\begin{array}{l}\text { Monitoring dan } \\
\text { pengawasan } \\
\text { berkala oleh } \\
\text { kepala ruang }\end{array}$ & $\begin{array}{l}80 \% \text { perawat } \\
\text { patuh dalam } \\
\text { melakukan } \\
\text { pendidikan } \\
\text { kesehatan kepada } \\
\text { pasien sesuai } \\
\text { dengan } \\
\text { kebutuhan pasien }\end{array}$ & 1 bulan \\
\hline
\end{tabular}


Gina Meirawaty : Field Experience : Manajemen Strategis pada Proses Manajemen Keperawatan

\begin{tabular}{|c|c|c|c|c|c|c|}
\hline No & Komponen & Area Prioritas & $\begin{array}{c}\text { Langkah Pemenuhan } \\
\text { Area Prioritas }\end{array}$ & $\begin{array}{c}\text { Metode } \\
\text { Perbaikan }\end{array}$ & $\begin{array}{c}\text { Indikator } \\
\text { Pencapaian }\end{array}$ & Waktu \\
\hline & & $\begin{array}{l}\text { kedaruratan,persiapan } \\
\text { pemeriksaan sebelum } \\
\text { kontrol }\end{array}$ & & & & \\
\hline & & $\begin{array}{l}89 \% \text { Perawat tidak } \\
\text { membahas temuan } \\
\text { penting dengan dokter } \\
\text { penanggung jawab untuk } \\
\text { penanganan kolaboratif } \\
\text { lebih lanjut. }\end{array}$ & $\begin{array}{l}\text { Meningkatkan peran } \\
\text { perawat dalam IPCP }\end{array}$ & Sosialisasi IPCP & $\begin{array}{l}75 \% \text { perawat } \\
\text { terpapar IPCP }\end{array}$ & 1 bulan \\
\hline & & $\begin{array}{l}60 \% \text { Perawat tidak } \\
\text { mendokumentasikan } \\
\text { segala tindakan yang } \\
\text { dilakukan pada pasien, } \\
\text { serta respon dan } \\
\text { perkembangan } \\
\text { kondisinya. }\end{array}$ & $\begin{array}{l}\text { Meningkatkan } \\
\text { kepatuhanperawatdala } \\
\text { m melakukan } \\
\text { pendokumentasian } \\
\text { segala tindakan yang } \\
\text { dilakukan pada } \\
\text { pasien,serta respon dan } \\
\text { perkembangan } \\
\text { kondisinya }\end{array}$ & $\begin{array}{l}\text { Monitoring dan } \\
\text { pengawasan } \\
\text { berkala oleh } \\
\text { kepala ruang }\end{array}$ & $\begin{array}{l}80 \% \text { perawat } \\
\text { patuh dalam } \\
\text { melakukan } \\
\text { pendokumentasia } \\
\text { n segala tindakan } \\
\text { yang dilakukan } \\
\text { pada pasien,serta } \\
\text { respon dan } \\
\text { perkembangan } \\
\text { kondisinya }\end{array}$ & 1 bulan \\
\hline & & $\begin{array}{l}\text { 69\% Pasien tidak } \\
\text { mendapatkan bantuan } \\
\text { dalam proses memenuhi } \\
\text { kebutuhan akan } \\
\text { kebersihan diri } \\
\text { (mandi,gosok gigi } \\
\text {,kebersihan rambut dan } \\
\text { kuku),apabila pasien } \\
\text { menginginkan } \\
\text { dimandikan keluarga } \\
\text { diperbolehkan sepanjang } \\
\text { tidak beresiko terhadap } \\
\text { perburukan kondisi } \\
\text { pasien }\end{array}$ & $\begin{array}{l}\text { Meningkatkan fokus } \\
\text { telaah, basis intervensi } \\
\text { dan lingkup garapan } \\
\text { perawat }\end{array}$ & $\begin{array}{l}\text { Monitoring dan } \\
\text { pengawasan } \\
\text { berkala oleh } \\
\text { kepala ruang }\end{array}$ & $\begin{array}{l}80 \% \text { perawat } \\
\text { patuh dalam } \\
\text { melakukan } \\
\text { pendidikan } \\
\text { kesehatan kepada } \\
\text { pasien sesuai } \\
\text { dengan } \\
\text { kebutuhan pasien }\end{array}$ & 1 bulan \\
\hline \multirow[t]{3}{*}{3} & $\begin{array}{l}\text { Staffing dan } \\
\text { Pengembangan } \\
\text { profesional }\end{array}$ & $\begin{array}{l}\text { Penataan dan } \\
\text { pendistribusian tenaga } \\
\text { belum berdasarkan } \\
\text { jenjang karir. }\end{array}$ & $\begin{array}{l}\text { Membentuk tim } \\
\text { untukPenataan dan } \\
\text { pendistribusian tenaga } \\
\text { belum berdasarkan } \\
\text { jenjang karir }\end{array}$ & $\begin{array}{l}\text { Sudah ada tim } \\
\text { Penataan dan } \\
\text { pendistribusian } \\
\text { tenaga belum } \\
\text { berdasarkan } \\
\text { jenjang karir } \\
\text { berdasarkan SK } \\
\text { Direktur RS }\end{array}$ & $\begin{array}{l}\text { Sudah ada draft } \\
\text { Penataan dan } \\
\text { pendistribusian } \\
\text { tenaga belum } \\
\text { berdasarkan } \\
\text { jenjang karir }\end{array}$ & 6 bulan \\
\hline & & $\begin{array}{l}\text { Mapping perawat belum } \\
\text { berdasarkan PMK No. } \\
\text { 40 Tahun } 2017\end{array}$ & $\begin{array}{l}\text { Membentuk tim untuk } \\
\text { Mapping perawat } \\
\text { belum berdasarkan } \\
\text { PMK No. } 40 \text { Tahun } \\
2017\end{array}$ & $\begin{array}{l}\text { Sosialisasi dan } \\
\text { bedah PMK No. } \\
\text { 40 Tahun } 2017\end{array}$ & $\begin{array}{l}\text { Terbentuk draft } \\
\text { mapping perawat } \\
\text { sesuai dengan } \\
\text { PMK No. } 40 \\
\text { Tahun } 2017\end{array}$ & 6 bulan \\
\hline & & $\begin{array}{l}\text { Metode penugasan } \\
\text { dalam bentuk tim, akan } \\
\text { tetapi belum dapat } \\
\text { berjalan secara optimal } \\
\text { dalam hal:Profesional } \\
\text { Relationship (Hand over, } \\
\text { Confeence, Kolaburasi, } \\
\text { delegasi, negosiasi), } \\
\text { Patient Care Delivery } \\
\text { System (SAK dan SOP, } \\
\text { Edukasi pasien), } \\
\text { Compensation for } \\
\text { Professional }\end{array}$ & $\begin{array}{l}\text { Menguatkan kembali } \\
\text { sistem pelayananan } \\
\text { keperawatan dengan } \\
\text { sistem SP2KP metode } \\
\text { tim }\end{array}$ & $\begin{array}{l}\text { Inhouse training } \\
\text { SP2KP metode } \\
\text { tim }\end{array}$ & $\begin{array}{l}\text { Metode tim dapat } \\
\text { berjalan secara } \\
\text { optimal, terdapat } \\
\text { ruang model }\end{array}$ & 1 bulan \\
\hline
\end{tabular}


Gina Meirawaty : Field Experience : Manajemen Strategis pada Proses Manajemen Keperawatan

\begin{tabular}{|c|c|c|c|c|c|c|}
\hline No & Komponen & Area Prioritas & $\begin{array}{c}\text { Langkah Pemenuhan } \\
\text { Area Prioritas }\end{array}$ & $\begin{array}{c}\text { Metode } \\
\text { Perbaikan }\end{array}$ & $\begin{array}{c}\text { Indikator } \\
\text { Pencapaian }\end{array}$ & Waktu \\
\hline & & $\begin{array}{l}\text { Achievement (Jenjang } \\
\text { karir, Sertifikasi, } \\
\text { Pelatihan), Pendekatan } \\
\text { manajemen (POAC). }\end{array}$ & & & & \\
\hline \multirow[t]{2}{*}{4} & $\begin{array}{l}\text { IPCP (Inter } \\
\text { Professional } \\
\text { Colaoration } \\
\text { Practice) }\end{array}$ & $\begin{array}{l}\text { Sistem komunikasi } \\
\text { SBAR dan TBAK masih } \\
\text { belum optimal. }\end{array}$ & $\begin{array}{l}\text { Menguatkan kembali } \\
\text { teknik komunikasi } \\
\text { SBAR dan TBAK }\end{array}$ & $\begin{array}{l}\text { Inhouse training } \\
\text { Teknik } \\
\text { komunikasi } \\
\text { SBAR dan } \\
\text { TBAK }\end{array}$ & $\begin{array}{l}80 \% \text { Perawat } \\
\text { paham tentang } \\
\text { komunikasi } \\
\text { SBAR dan } \\
\text { TBAK }\end{array}$ & 1 bulan \\
\hline & & $\begin{array}{l}\text { IPCP belum dapat } \\
\text { berjalan }\end{array}$ & Sosialisasi IPCP & Seminar IPCP & $\begin{array}{l}75 \% \text { perawat } \\
\text { terpapar IPCP }\end{array}$ & 3 Bulan \\
\hline \multirow[t]{2}{*}{5} & $\begin{array}{l}\text { Perawatan } \\
\text { berpusat pada } \\
\text { pasien/ patient } \\
\text { centered care }\end{array}$ & $\begin{array}{l}\text { Masih ada beberapa } \\
\text { perawat yang belum } \\
\text { paham konsep PCC }\end{array}$ & $\begin{array}{l}\text { Menguatkan kembali } \\
\text { konsep PCC }\end{array}$ & $\begin{array}{l}\text { Inhouse training } \\
\text { konsep PCC }\end{array}$ & $\begin{array}{l}80 \% \text { Perawat } \\
\text { paham konsep } \\
\text { PCC }\end{array}$ & 1 bulan \\
\hline & & $\begin{array}{l}\text { PCC belum dapat } \\
\text { berjalan secara optimal }\end{array}$ & $\begin{array}{l}\text { Menguatkan kembali } \\
\text { konsep PCC }\end{array}$ & $\begin{array}{l}\text { Inhouse training } \\
\text { konsep PCC }\end{array}$ & $\begin{array}{l}80 \% \text { Perawat } \\
\text { paham konsep } \\
\text { PCC }\end{array}$ & 1 bulan \\
\hline 6 & $\begin{array}{l}\text { Riset klinik } \\
\text { dan pelayanan } \\
\text { berbasis bukti } \\
\text { ilmiah }\end{array}$ & $\begin{array}{l}\text { Belum ada perawat yang } \\
\text { melakukan penelitian }\end{array}$ & $\begin{array}{l}\text { Membentuk tim } \\
\text { penelitian keperawatan }\end{array}$ & $\begin{array}{l}\text { Sudah ada tim } \\
\text { Penataan dan } \\
\text { pendistribusian } \\
\text { tenaga belum } \\
\text { berdasarkan } \\
\text { jenjang karir } \\
\text { berdasarkan SK } \\
\text { Direktur RS }\end{array}$ & $\begin{array}{l}\text { Sudah ada } \\
\text { penelitian } \\
\text { keperawatan }\end{array}$ & 1 bulan \\
\hline 7 & $\begin{array}{l}\text { Pengelolaan } \\
\text { informasi klinis }\end{array}$ & Belum ada SIMKEP. & $\begin{array}{l}\text { Membentuk tim } \\
\text { pengadaan software } \\
\text { SIM Keperawatan } \\
\text { (computerized) }\end{array}$ & $\begin{array}{l}\text { Mengajukan } \\
\text { usulan } \\
\text { pengadaan } \\
\text { software SIM } \\
\text { Keperawatan } \\
\text { (computerized) } \\
\end{array}$ & $\begin{array}{l}\text { Adanya } \\
\text { pengajuan usulan } \\
\text { pengadaan } \\
\text { software SIM } \\
\text { Keperawatan } \\
\text { (computerized) }\end{array}$ & 12 bulan \\
\hline
\end{tabular}

Dari prioritas area need to be improve tersebut dibuat plan of action dengan pertimbangan 5M (man, material, methode, machine, money) diperoleh 4 kegiatan besar yaitu :

1. In house training (IHT) SP2KP metode Tim, Komunikasi efektif

2. Pengelolaan Ruang Model Penerapan SP2KP, Penguatan Metode Tim, Komunikasi

Efektif (SBAR, TBAK), Inovasi Diskusi Refleksi Kasus

3. IHT Audit Mutu Asuhan Keperawatan

4. Sosialisasi dan bedah PMK No.40 tahun 2017 tentang Jenjang Karir Perawat

\section{Pembahasan}

Kegiatan IHT SP2KP berfokus pada perawat ruang rawat inap dimana dalam hal ini metode Tim yang dilakukan di ruang rawat inap. Metode keperawatan yang sering 
digunakan adalah asuhan keperawatan metode tim. Asuhan keperawatan metode tim dikenal di Indonesia pada tahun 1996 yang telah diterapkan dibeberapa rumah sakit. Metode ini merupakan suatu metode pemberian asuhan keperawatan pada sekelompok klien melalui upaya kooperatif dan kolaboratif (Douglas, 1984 dalam Simamora, 2013). Keuntungan menggunakan metode tim adalah memfasilitasi pelayanan keperawatan yang komprehensif dan memungkinkan pencapaian proses keperawatan. Kerugiannya adalah rapat tim memerlukan waktu, sehingga mengganggu komunikasi dan koordinasi anggota tim dalam memberikan asuhan keperawatan pada pasien (Simamora, 2013).

Pelaksanaan metode tim menggunakan tim yang terdiri dari anggota yang berbeda-beda dalam memberikan asuhan keperawatan terhadap kelompok pasien. Perawat ruangan dibagi menjadi 2-3 tim/group yang terdiri dari perawat profesional, teknikal, dan pembantu dalam satu tim kecil yang saling membantu. Metode ini didasarkan pada keyakinan bahwa setiap anggota kelompok mempunyai kontribusi dalam merencanakan dan memberikan asuhan keperawatan sehingga timbul motivasi dan rasa tanggung jawab perawat yang tinggi (Tussaleha, 2014). Menurut Arwani dan Supriyatno (2006) pemberian metode tim pada asuhan keperawatan bertujuan untuk memberikan asuhan keperawatan sesuai dengan kebutuhan objektif pasien sehingga pasien merasa puas.

Metode tim juga dapat meningkatkan pengetahuan, ketrampilan, dan motivasi perawat karena dalam metode ini ada kerjasama antar sesama perawat dan transfer of knowledge.Untuk tercapainya tujuan tersebut maka tugas dan tanggung jawab dari tim keperawatan harus diarahkan dan benar-benar direncanakan serta memiliki ketua tim yang profesional. Menurut Huber (2010), Marquis \& Huston (2012) dikutip dalam Rusmianingsih (2012) dan Swansbrug (2000) Faktor yang mempengaruhi dari metode tim yaitu kepemimpinan, komunikasi, koordinasi, penugasan, motivasi dan supervisi. Sitorus (2006) mengatakan ketua tim sebagai perawat profesional, harus mampu menggunakan berbagai teknik kepemimpinan dan harus dapat membuat keputusan tentang prioritas perencanaan, supervisi, serta evaluasi asuhan keperawatan. Ketua tim harus mampu mengontrol setiap perkembangan pasien, keberhasilan asuhan keperawatan sangat ditentukan oleh ketua tim yang profesional. 
Pengelolaan ruang model penerapan SP2KP, penguatan metode tim, komunikasi efektif (SBAR, TBAK), dan inovasi diskusi refleksi kasus sesuai kesepakatan dengan bidang keperawatan dan wakil direktur pelayanan ruang model untuk penerapan SP2KP yaitu ruang Marjan Bawah dan Agate Atas, uji coba dilakukan selama 3 minggu. Dimana perawat ruangan terbagi menjadi 3 Tim masing-masing ruangan, dilakukan penghitungan kebutuhan perawat sesuai tingkat ketergantungan pasien sehingga jumlah perawat proporsional sesuai kebutuhan. Penerapan komunikasi efektif dengan prosedur SBAR dan TBAK dilakukan dengan disediakan nya fasilitas komunikasi yaitu buku komunikasi sesuai format SBAR dan TBAK. Kemudian dilakukan analisis terhadap kasus yang muncul diruangan meliputi prognosis penyakit dan proses asuhan keperawatan yang diberikan difasilitasi dengan buku refleksi kasus dan forum diskusi.

\section{Simpulan}

Berdasarkan kajian situasional diperoleh data proses pelayanan kesehatan malalui alur pasien dari mulai pasien masuk hingga keluar meliputi kualitas pelayanan pasien berdasarkan peran dan fungsi keperawatan. Berfokus pada pilar tata kelola klinis, pilar kedua sistem penjaminan mutu dan audit klinis dan pilar ketiga staffing dan pengembangan profesional (CPD). Perencanaan perbaikan strategis berdasarkan prioritas rawat inap RSUD dr. Slamet Garut yang berfokus pada quality improvement meliputi 5M man, material, money, method dan machine. Berdasarkan plan of action intervensi dilakukan terhadapa peningkatan man melalui knowledge, skill dan attitude.

Kegiatan yang dilakukan yang pertama kegiatan In House Training (IHT) SP2KP Dan Role Play Teknik Komunikasi SBAR Dan TBAK dengan hasil tingkat Pengetahuan dari $57 \%$ naik menjadi $69 \%$ (12\%). Disepakati untuk ruang model SP2KP adalah ruang Marjan Bawah dan Agate Atas. Peningkatan kualitas pelayanan yang berfokus pada 5M, selama rangkaian kegiatan yang dilakukan peningkatan akan pengetahuan, kemampuan terhadap pelayanan terutama keperawatan. Outcome utama yaitu menyusun perangkat kebutuhan sumber daya manusia dengan melihat tingkat ketergantungan, dan yang kedua menyusun prototype pelayanan keperawatan pasien sebagai revenue center.

Melalui dua ruangan yang dijadikan sebagai room models dapat dianalisis dan memberikan gambaran untuk rencana tindak lanjut sebagai berikut perlu ada kebijakan 
dari bidang pelayanan keperawatan terkait dengan sistem pemberian asuhan keperawatan di ruang rawat inap. Kemudian perlu dilakukan kajian berkesinambungan kebutuhan SDM berdasarkan tingkat ketergantungan pasien. Membangun sebuah komitmen untuk pelaksanaan hand over dan didukung dengan sebuah kebijakan oleh bidang keperawatan. Dalam mendukung pelayanan keperawatan yang optimal perlu dibuatkan panduan praktek klinis (PPK) keperawatan untuk 10 diagnosa terbanyak dan perlu di inisiasi dengan profesi medis terkait clinical pathway (CP) terintegrasi. Selain itu perlu ada kebijakan dari bidang pelayanan keperawatan terkait dengan sistem pemberian asuhan keperawatan di ruang rawat inap. Perlu dilakukan kajian berkesinambungan kebutuhan SDM berdasarkan tingkat ketergantungan pasien. Rumah sakit dalam mengefektifkan dan mengefisiesnikan perlu mulai menghitung revenue centre pelayanan keperawatan berdasarkan tingkat ketergantungan.

\section{Daftar Pustaka}

Anjaryani, W. D. (2009). Kepuasan pasien rawat inap terhadap pelayanan perawat di RSUD Tugurejo Semarang(Doctoral dissertation, Universitas Diponegoro).

Arwani \& Supriyatno (2006). Manajemen bangsal keperawatan. (Cetakan Pertama). Jakarta: EGC.

Asih \& Pratiwi. (2010). Perilaku prososial ditinjau dari empati dan kematangan emosi. Jurnal Psikologi, 1(1).

Dewi, R., Janitra, P. A., \& Aristi, N. (2018). Pemanfaatan Internet Sebagai Sumber Informasi Kesehatan Bagi Masyarakat. Media Karya Kesehatan, 1(2).

Dewi, P. K. (2018). Analisis Alur Proses Penerimaan Pasien Rawat Inap di Rumah Sakit "X" Tahun 2015 dengan Pendekatan Lean Hospital. Jurnal Administrasi Rumah Sakit Indonesia, 2(1).

Huber, D. (2010). Leadership and nursing care management (4rd ed). USA.

Kuntoro, A. (2010). Buku ajar manajemen keperawatan. Yogyakarta: Nuha Medika.

Kusnanto. (2004). Pengantar Profesi dan Praktik Keperawatan Profesional. Jakarta: EGC.

Marquis, B.L \& Huston C.J. (2013). Kepemimpinan dan manajemen keperawatan. Alih bahasa Widyawati, dkk. Jakarta: EGC. 
Nazri, F. (2015). Implementasi Komunikasi Efektif Perawat-Dokter dengan Telepon di Ruang ICU Rumah Sakit Wava Husada. Jurnal Kedokteran Brawijaya, 28(2), 174-180.

Rusmianingsih, (2012). Hubungan penerapan metode pemberian asuhan keperawatan dengan kepuasan kerja di instalasi rawat inap Rumah Sakit Umum Kabupaten Tanggerang tahun 2012. Tesis. Program Studi S2 Ilmu Keperawatan UI Depok.

Simamora, R. (2013). Buku ajar manajemen keperawatan. Jakarta: EGC.

Sitorus, Ratna. (2006). Model Praktik Keperawatan Profesional di Rumah Sakit : Penataan Struktur \& Proses (sistem) Pemberian Asuhan Keperawatan di Ruang Rawat. Jakarta : EGC.

Sitorus \& Panjaitan. (2011). Manajemen keperawatan: manajemen keperawatan di ruang rawat. Jakarta: EGC.

Sumijatun. (2010). Konsep dasar menuju keperawatan profesional. Jakarta: TIM

Susilowati, E. (2019). Penerapan Komunikasi TBAK (Tulis, Baca, Konfirmasi) dalam Penyampaian Informasi Kepada Mahasiswa AKPER Dharma Husada. JURNAL ILKES (Jurnal Ilmu Kesehatan), 10(1), 10-15.

Sutrisari, S. N. (2018). Pengalaman Perawat Dalam Melaksanakan Komunikasi Efektif: Sbar (Situation, Background, Assesment Recommendation) Di Ruang Rawat Inap Flamboyan Rumah Sakit Pusri Palembang(Doctoral dissertation, Universitas Andalas).

Swanburg, Russel C. (2000). Pengantar kepemimpinan dan manajemen keperawatan untuk perawat klinis. Alih bahasa Samba S, Dkk. Jakarta: EGC.

Tussaleha. (2014). Hubungan penerapan metode tim dengan kinerja perawat pelaksana di ruang rawat inap interna di RSUD Daya Kota Makassar. Jurnal Ilmiah Kesehatan Diagnosis, 5(3). 